\title{
The Effects of e-Business on Supply Management
}

\author{
Anni-Kaisa Kähkönen \\ Lappeenranta University of Technology, School of Business \\ P.O. Box 20, FI-53851 Lappeenranta Finland \\ Email: anni-kaisa.kahkonen@lut.fi (Corresponding author) \\ Katrina Lintukangas \\ Lappeenranta University of Technology, School of Business \\ P.O. Box 20, FI-53851 Lappeenranta Finland \\ Email: katrina.lintukangas@lut.fi \\ Veli Matti Virolainen \\ Lappeenranta University of Technology, School of Business \\ P.O. Box 20, FI-53851 Lappeenranta Finland \\ Email: vmv@lut.fi
}

\begin{abstract}
The exploitation of e-business has become one of the primary conditions of doing business in the current business environment. Companies have moved to web-based business to business platforms where transactions are done efficiently and in a fast pace. The importance of e-business technology has grown significantly in supply management as well. Therefore, this study examines the effects of e-business on supply management using data collected from 100 Finnish firms. Moreover, light is shed on the targets of e-business and the changes caused by e-business in supply management and how these changes have influenced the firm's competitive and bargaining positions. The results of the study show that the main targets of e-business in supply management are cost and time savings and process development. It was also found that $e-$ business has caused changes in supply chains and networks in terms of bargaining and competitive position.
\end{abstract}

Keywords: e-business, supply management, value creation, survey

\section{INTRODUCTION}

In the increasingly complex world of globalized trade with extended lead times, greater risks and longer-term partnering, the integration of processes and systems in the supply chain and network requires supportive information systems and technology (Smart, 2008). Companies have moved to web-based business-to-business (B2B) platforms promoting efficiency and speed. The need to implement ebusiness technologies has grown significantly in business in general, and in strategic and operational supply management in particular. Companies are increasingly recognizing the need to implement e-business technologies, and as Wiengarten et al. (2011) state, companies are continuously investing and implementing e-business applications to streamline their business processes through integrating and coordinating their supply chain processes. Johnson et al.
(2007) state, there has been substantial managerial interest in seeking such opportunities in the supply chain in order to create competitive advantage. Moreover, new models of ebusiness may be a source of value creation for firms and supply networks in the current dynamic business environment (Amit and Zott, 2001).

It has been suggested that the implementation of ebusiness technologies will change business patterns, especially in the field of supply management (see e.g., Chong et al., 2009; Croom, 2005; Lancioni et al., 2000; Vakharia, 2002). Caniato et al. (2009) have stated that internet-based tools are spreading across firms in different industries and contexts, reshaping supply chain management strategies and practices. In the previous research, for example, Croom (2005), de Boer et al. (2002), and Kritchanchai (2012), have highlighted the role of e-business and e-tools in the improvement process of supply chains. The previous research has recognized the trend and the need of varying e-business tools and concepts, but the empirical evidence concerning the changes caused by e-business is still lacking. Moreover, Wiengarten et al. (2011) state that despite the key role that e-business plays in the supply chain more research on its value development is still needed. This empirical study therefore examines the changes e-business has brought about, and how they have influenced the companies' competitive and bargaining positions. The aim is to find answers to the following research questions: 1) What are the targets of e-business in supply management?, 2) What are the changes caused by e-business in supply management?, 3) Does e-business change the bargaining position in a supply network?, and 4) Does e-business change the competitive position in a supply network? Survey data collected from one hundred Finnish firms is used in addressing these questions. Hence, the empirical research is quantitative by nature. 


\section{THE VALUE-CREATION ROLE OF E-BUSINESS AND FORCES OF COMPETITION}

\subsection{E-business}

E-business technology constitutes a powerful tool in contemporary supply management. Efficient information integration between supply chain members offers several advantages for the business partners, such as the automation of routine work, faster lead times, process transparency and opportunities for further improvements (Goutsos and Karacapilidis, 2004). Moreover, Power (2008) stated that potential benefits of utilizing technologies in supply chain management may also include, for example, open information sharing, increased visibility of customer demand, decrease in delivery lead times, improved visibility and the development of core competences. Zakaria et al. (2010) studied the role of information technology in logistics and stated that information technology can have significant effects on logistics operations because it facilitates, for example, collaboration and automation which, moreover, makes possible for managers to focus on more strategic issues. As Sanders (2007) states, information technology has made it possible to share large amounts of information along the supply chain, and it is often referred to as an essential enabler of supply chain management activities. However, Power (2008) found that in the field of supply chain management organizations can achieve many kinds of benefits by applying different technologies but the implementation of those can be limited.

Sanders (2007) has defined that information technologies which use the internet, web and web-based applications for communication are termed e-business technologies in the literature. Croom (2005) defines ebusiness as the "use of systems and open communication channels for information exchange, transactions and knowledge sharing between organizations." According to Johnson and Wang (2002), e-business applications can be divided into e-commerce, e-procurement and ecollaboration. E-commerce has been defined to be useful in terms of identifying possible exchange partners and responding quickly to changing customer demands, and it more specifically, relates to buying and selling products on the internet. E-commerce is linked to individual consumers, whereas e-procurement usually involves dealing with companies (Johnson and Wang, 2002).

Johnson and Wang (2002) define e-procurement as efficient purchasing using the internet or other pre-specified protocols to carry out transactions between buyer and supplier companies. Tanner et al. (2008) further define eprocurement as the electronic support of the professional buying process, referring to the relationships between a business and its suppliers. It also encompasses a number of specific elements, including e-sourcing, e-coordination and e-communities (Johnson and Klassen, 2005). Moreover, Chang et al. (2013) define e-procurement as an electronic procurement system that has four functions: e-design, esourcing, e-negotiation and e-evaluation. Kalakota and Robinson (2001), on the other hand, identify several e- procurement models in which the number of users, their nature and how they exploit information technology vary remarkably.

E-collaboration, which is the third e-business application according to Johnson and Wang (2002), consists of B2B interactions beyond buying and selling transactions, including relationship management and the sharing of processes, resources and decisions. It could thus be stated that e-business is an overall concept involving e-commerce, e-procurement and e-collaboration. It incorporates production, customer and firm-internal processes that are indirectly related to commercial transactions (Lysons and Farrington, 2006). Because the aim of the study is to discuss the changes e-business has brought and not, for example, to focus on e-procurement purely, the definitions of earlier literature are followed and the term e-business is used in the study.

\subsection{Value creation}

In the environment of changing business patterns one of the key questions to be addressed concerns how to employ the internet and e-business and develop new business models for generating value. Firms need to define the content of their business, its participants, the ways in which the participants are linked with each other, and the governance of the flows of information, goods and resources. As Amit and Zott (2001, p. 511) put it, "A business model depicts the content, structure, and governance of transactions designed so as to create value through the exploitation of business opportunities".

A critical issue in all types of business is the ability to create value and the underlying system through which such value is produced (Möller and Rajala, 2007; Möller et al., 2005). Each product or service requires a set of valuecreating activities performed by a number of actors forming a value-creating system (Möller and Rajala, 2007). According to Amit and Zott (2001), theories of strategic management and entrepreneurship do not explicitly explain the sources of new value creation in e-business, and an integrative perspective is required. Basing their arguments on various theoretical perspectives - value-chain analysis, Schumpeterian innovation, the resource-based view of the firm, strategic network theory and transaction cost economics - they identify the four major value drivers of ebusiness as efficiency, complementarity, lock-in and novelty: together they characterize its environmental dynamics and value-creation potential.

Previous studies have presented a value net model as a business model which facilitates the value creation in current business environment. A value net (or value network, value web, value-creating net) is a dynamic, flexible network in which the actors create value through collaboration (Allee, 2003; Bovet and Martha, 2000; Möller et al., 2005). The value net model was developed to facilitate the analysis, description and study of value-creating systems, and takes activities rather than companies as the key elements of strategic analysis. Companies are regarded as complex nodes in complex interdependent value networks, in which success comes through collaboration and creating a business environment in which each actor can be successful (Allee, 2003). 
The use of technologies has been defined to be one of the most critical characteristics of value nets for example in the studies by Allee (2003), Bovet and Martha (2000), Kothandaraman and Wilson (2000), Kähkönen (2012), Möller et al. (2005) and Parolini (1999). Moreover, also information sharing and the ability to respond rapidly have been defined to be the characteristics of value nets (e.g., Allee, 2003; Bovet and Martha, 2000; Kähkönen, 2012). These reflect the value net models ability to enable value creation in the e-business world where new models for competitive advantage and value creation need to be defined. Moreover, value net model offers companies a new business model in the light of competition and strategic positioning.

\subsection{Forces of competition}

E-business tools potentially offer companies great opportunities to establish distinctive strategic positions. It has been shown that the use of e-business technologies affects operational effectiveness and strategic positioning in different ways (Chong et al., 2009). E-business may make it harder for companies to sustain operational advantage, but it opens up new opportunities for achieving or strengthening a distinctive strategic position. For example, the internet is the most powerful tool available today for enhancing operational effectiveness, but simply improving operational effectiveness does not provide competitive advantage (Porter, 2001). Hence, strategic positioning is becoming more important.

Porter (2001) lists the following six principles a company has to observe if it wants to achieve and sustain a distinctive strategic position: 1) aiming at the right goal, in other words superior long-term return on investment, 2) focusing on value proposition, meaning providing benefits that differ from those of competitors, 3) having a distinctive value chain carrying out different activities or similar activities in different ways than the rivals, 4) engaging in strategy trade-offs, in other words making sacrifices in order to achieve uniqueness, 5) ensuring fit, meaning that all activities must be mutually reinforced, and 6) maintaining continuity in terms of strategic direction in order to ensure continuous improvement. Furthermore, the internet shapes industry structures through the forces of competition: rivalry among existing competitors, the threat of new entrants, the threat of substitute products or services, and the shift of bargaining power (see also Porter, 2008).

\section{METHODOLOGY}

The aim in this study is to describe some of the effects of e-business on a firm's supply management. The focus is on the targets and objectives, and the changes in bargaining power and competitive position it brings about. The objective is thus to answer the four research questions concerning these issues. An extensive survey was conducted among large Finnish firms in order to achieve this objective.

\subsection{Sample and data collection}

The empirical data was collected by means of a structured survey of large Finnish firms with a turnover of at least 50 million euros. The company register of Statistics Finland identified 570 companies. These companies were contacted by telephone in order to reach the suitable key informant to answer and to inform the respondent of questionnaire beforehand. The aim of the telephone contacts was also to increase the response rate. Some of the companies or respondents were not reached in spite of numerous telephone calls. However, the questionnaire, preaddressed postage-paid return envelope, and the covering letter describing the purpose of the research, were mailed to all eligible respondents whether they had been personally contacted or not. Besides a telephone contact, participation in the survey was solicited by means of incentives such as the offer of a summary report of the results and by assuring the confidentiality of the responses. A reminder e-mail was sent to those who had not answered within two weeks.

A total of 100 responses were received, the response rate thus being 17.5 per cent. Non-response bias was assessed on a number of variables (e.g., size of staff and turnover, market share, year of foundation) by comparing early and late respondents, following the suggestions of Armstrong and Overton (1977). The Mann-Whitney tests and t-tests were used to compare the responses of the first 30 and the last 30 respondents, and there was no evidence of non-response bias.

\subsection{Description of the respondents}

On average, the turnover of the respondent companies was 322.8 million euros. Half of the respondent firms (51\%) had been established before the year $1975.47 \%$ of the companies had less than 500 full-time employees and $23 \%$ more than one thousand. The basic information of the responding companies and respondents are summarized in Table 1.

Table 1. Basic information of the respondent companies

\begin{tabular}{lrrrrr}
\hline & Mean & Median & Std. deviation & Minimum & Maximum \\
\hline Turnover (million $€$ ) & 322.77 & 129 & 1194.39 & 10.2 & 11392 \\
Year of foundation & 1959.3 & 1971.5 & 43.5 & 1818 & 2002 \\
Number of staff & 1161.84 & 512.5 & 2197.74 & 2 & 13700 \\
\hline
\end{tabular}


As Figure 1 illustrates, twelve per cent of the respondent companies represented trade, $6 \%$ information technology, $17 \%$ the chemical industry, $9 \%$ the energy industry, $14 \%$ construction, $21 \%$ metals and machinery, 10
$\%$ traffic and services, and $11 \%$ the forest and other industries. Most of the companies operated internationally $(62 \%)$ and $32 \%$ carried on business domestically.

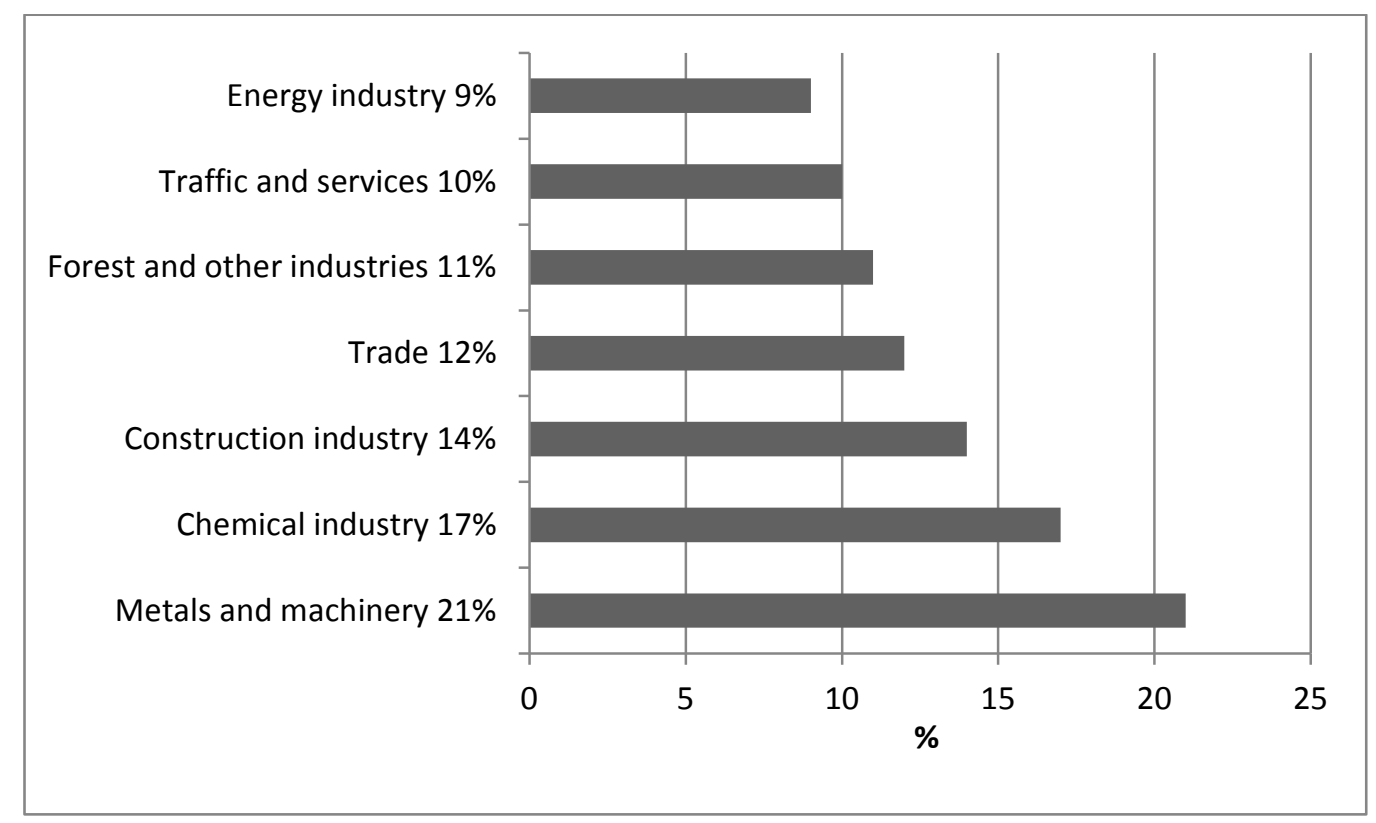

Figure 1. The respondents categorized by industry.

The questionnaire was addressed to the general executives from top management and the directors responsible for supply management. Of the respondents, 76 $\%$ worked in the area of sourcing, and over half of them had more than five years' experience in their current positions. In order to assess the effects of e-business on supply management the respondents were asked to evaluate several statements on a five-point Likert scale ranging from "fully disagree" to "fully agree". The next section presents and discusses the main results of the study.

\section{RESULTS AND DISCUSSION}

\subsection{Targets}

Companies aim at more efficient operation, and in the current dynamic business environment they utilize ebusiness technologies to achieve efficiency and benefits. Croom (2005) suggests that the primary strategic objectives of e-business implementation in supply management include the management and integration of supply, price pressure and cost reduction, knowledge development and learning, the control of intellectual property and information flow, and adaptation to the speed of change. The effective management of global customers and suppliers, the development of eprocurement practices and lead-time management are also crucial. According to Johnson et al. (2007), the potential benefits of e-business technologies include lower prices from suppliers, improved speed and flexibility, lower transaction costs, higher customer-service levels and reduced investment in supply-chain inventories. Furthermore, on the evidence of previous literature Tanner et al. (2008) suggest that electronic procurement systems are likely to lead to cost reduction and increased efficiency with inbound logistics.

According to several studies (Chong et al., 2009; Johnson et al., 2007; Sanders, 2007), conducting e-business in supply management makes it possible to reduce transaction costs in particular. Essig and Arnold (2001) found that e-procurement helped to lower such costs by making a wide range of information available to buyers. It could be argued that one of the primary targets of implementing e-business in supply management is to reduce costs, although many studies also highlight the changing and development of processes. As de Boer et al. (2002) state, electronic procurement may bring about changes in strategic, tactical and operational purchasing processes: some elements may diminish in importance whereas others may need more or less time, and new activities may be incorporated. As a consequence, the organizational structure could also change.

The results of this study indicated that two main targets of e-business in supply management among the Finnish firms surveyed were (see Figure 2): savings in costs and time (mean 4.21), and process development and business change (mean 4.05). However, a remarkable change or entirely new business was not found as a main target (mean 2.80). 


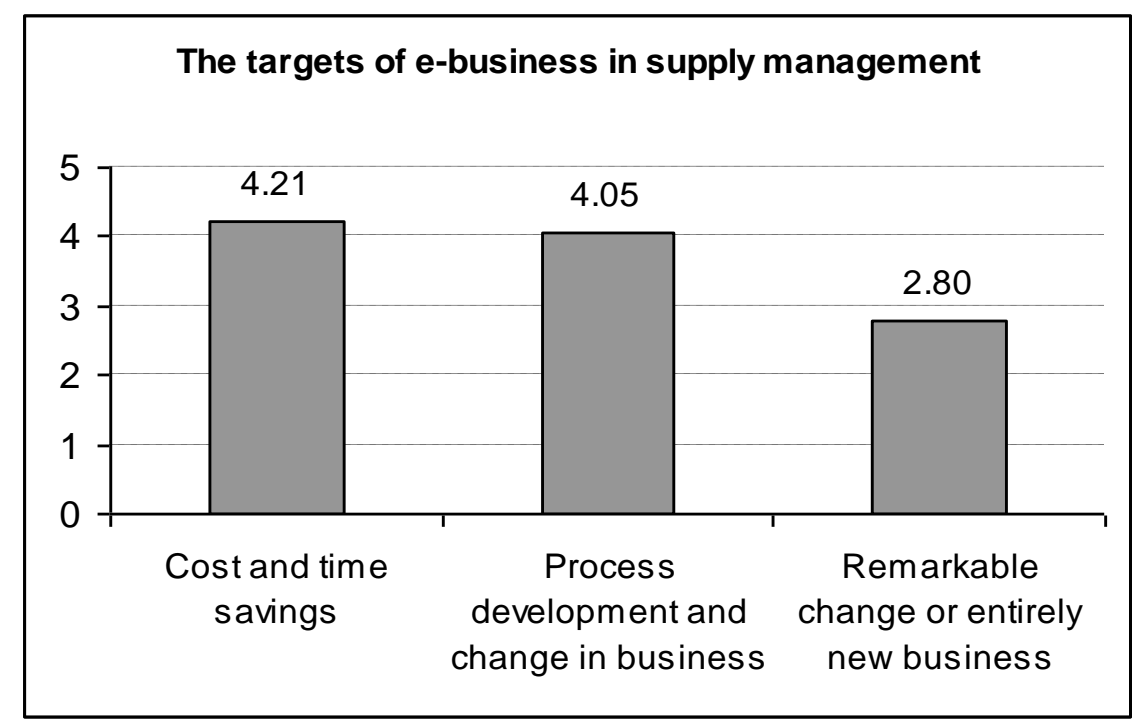

Figure 2. The main targets of e-business in supply management.

As mentioned above, previous research (see e.g., Bakos, 1997; de Boer et al., 2002; Giunipero and Sawchuck, 2000; Subramaniam and Shaw, 2004) has identified savings in costs and time as main targets of e-business utilization in supply management. Furthermore, many studies (see e.g., Barua et al., 2004; Croom and Brandon-Jones, 2007; Lancioni et al., 2000; Pearcy et al., 2004) note the tendency to further develop processes and the whole business when the company is using e-business technologies. The results of this study provide similar evidence. Hence, it could be argued that companies implement e-business technologies in their supply management in order to achieve savings in cost and time and also to develop their processes and their business.

\subsection{Major changes}

According to Lancioni et al. (2000), the use of the internet and e-business potentially leads to cost reduction and service improvement in several operating areas including transportation, inventories, purchasing, customer service, production scheduling, order processing and supplier operations. They studied how and to what extent the internet was used in these areas, and found a rapidly increasing tendency to use it in supply chain management. Furthermore, e-business technology facilitates fast and accurate information exchange, which is the key success factor in managing a supply chain.

Gunasekaran et al. (2009) have found that the main benefits of e-procurement in supply management have come true in supplier relationship management. Close collaboration with suppliers require smooth flow of information, and streamlined approval and workflow processes. However, there are several concerns when utilizing and implementing e-tools. For example fear of change and fear of being tied to specific IT technology provider may hinder the pace of implementation. Furthermore, immature technologies, security concerns, and expensive IT investments are major barriers of e-business. Moreover, problems related to e-business implementation process in a context of supply management have been reported in several studies (e.g. Muffatto and Payaro, 2004; Panayiotou et al., 2004). Therefore, e-business technology initiatives must have top management involvement and support.

The fast and accurate exchange of information is one of the main changes e-business implementation has brought about. Moreover, delivery times are faster and some tasks or parts of processes have become unnecessary (de Boer et al., 2002; Smart, 2008). These studies note the change in processes related to supplier relations and organizational structures, and in the content of work because many processes and activities are handled electronically.

The implementation of e-business technology has caused many changes to companies' supply management and supply processes. The main changes among the respondent firms in this study have been similar to those reported in previous research. According to the survey results, many functions have been transferred to suppliers, and processes related to the supplier relationship are changing. Thus, the content of the work is different. Furthermore, some company tasks have become unnecessary, but at the same time ebusiness has created new tasks. Table 2 shows the main changes that e-business technology has brought about in the supply management of the respondent firms. 
Table 2. Changes in supply management caused by e-business.

\begin{tabular}{lcc} 
& Mean & Std. Deviation \\
\hline Functions are transferred to suppliers & 3.69 & 0.97 \\
Processes related to supplier relations are changing & 3.68 & 0.88 \\
The inner functions of the organization have benefited from it & 3.67 & 0.98 \\
The content of work has changed & 3.57 & 1.05 \\
Some tasks have become unnecessary & 3.49 & 1.13 \\
The quality of business has risen & 3.48 & 1.03 \\
Delivery lead times have decreased & 3.44 & 1.05 \\
The organization has gained benefits from the supplier network & 3.38 & 1.04 \\
E-business has created new tasks & 2.91 & 1.16 \\
Customers' tasks are transferred to our functions & 2.90 & 1.09 \\
The gained benefits have been measured & 2.88 & 1.12 \\
\hline
\end{tabular}

\subsection{Bargaining position}

Even if cost reduction and process development are commonly seen as the main targets in the use of e-business in supply management, there are also other benefits that may not be so obvious such as the strengthening of bargaining positions.

Bargaining positions between buyers and suppliers are strategically significant, and power positions between the companies influence the characteristics of buyer-supplier relationships. Achrol (1997), for example, has stated that power is an essential characteristic of a social organization and an inevitable instrument for inter-organizational coordination. Cox (1997) defines the structure of power in business relationships in terms of analyzing and describing who gets what, where, how and when, and of the structures of dominance and dependence. Furthermore, Stannack (1996) defines power in supply chain management as the capacity to optimize the behaviour of suppliers and subcontractors in accordance with desired performance objectives. Purchasing power, on the other hand, is the capacity to achieve a successful negotiated contractual outcome on behalf of an organization. Power in this study is seen as the basis of the bargaining positions among buyers and suppliers.

Power among buyers and suppliers derives from different sources (see e.g., Bates and Slack, 1998; Cox et al., 2001; Doz and Hamel, 1998; Kähkönen and Virolainen, 2011; Ramsay, 1996), which also create the basis for their bargaining positions. According to Ramsay (1996), the buyer's power stems from a combination of the attractiveness of its own resources and the supplier's freedom to obtain resources from other organizations. The supplier's power, on the other hand, derives from the attractiveness of its own resources and the buyer's freedom to obtain resources from other organizations. According to Porter (2001), the supplier is powerful, for example, when a few companies dominate the market and the product is unique. Conversely, the buyer is powerful when purchases are of large volume, the products are standard or undifferentiated, the component being supplied represents a significant proportion of the product's costs, the product quality is of no importance, and the product does not save the buyer money.

Cox (1999) refers to the great variety of supply chains, each of which has a very different structural configuration of power. The differences in operational modes stem from the types of resources companies own and control, and the ways in which they own and control them vis-à-vis other supply chain members. Furthermore, certain strategies match certain supply chains and circumstances, and therefore companies must do what is appropriate given the relative power structures that operate within them. Cox (1999) also emphasizes the importance of understanding the power structures that exist in supply chains in order to be able to manage them strategically and operationally.

The power in supply chains and networks and in buyersupplier relationships may shift from one actor to another. According to Bates and Slack (1998), the balance shifts from the buyer to the supplier when the customer (i.e. the buyer) is significantly smaller than the supplier, and when the business represents a small proportion of the supplier's turnover but a large proportion of the customer's costs. There is also a shift when the supplier is in possession of key technologies: in a situation of up-front investment and lockin (when the supplier has specific tooling expertise, for example, which results in high switching costs for the customer) the power balance moves from the buyer to the supplier. Porter (2001) suggests that the use of internet technology may affect power positions and may shift power from one actor to another. E-business provides buyers with easier access to information about products and suppliers, thus increasing their bargaining power. Internet procurement and digital markets tend to give all companies equal access to suppliers, and gravitate procurement to standardized products that reduce differentiation. The bargaining power shifts to buyers and the costs of changing supplier will decrease. Bakos (1997) also found evidence that e-business reduces the market power of suppliers. The results of our study support this: the change in bargaining position seems to benefit the customer (=buyer) more than the supplier (see Figure 3). 


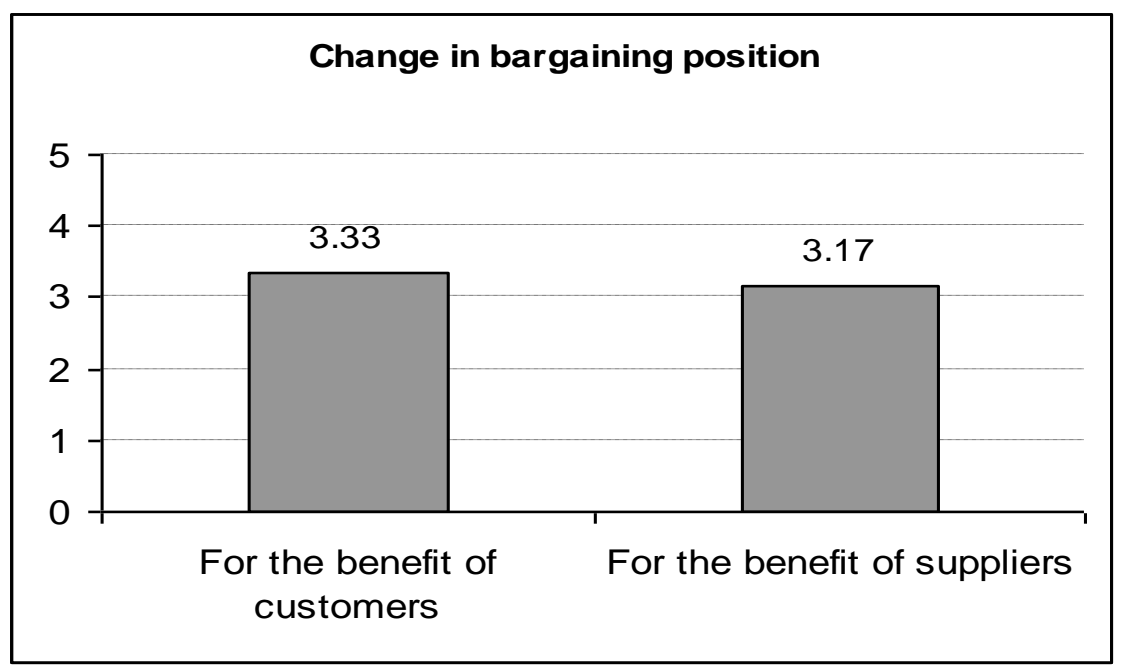

Figure 3. Change in bargaining position.

However, Porter (2001) also suggests that even if procurement via the internet tends to raise the bargaining power over suppliers, it may also give them access to more customers. Moreover, lower entry barriers and the proliferation of competitors downstream shifts power to suppliers. The internet provides a channel through which suppliers can reach end customers, thereby reducing the leverage of intervening companies. However, even if ebusiness increases the power of suppliers, the results of this study, in line with those of previous research, indicate that it has changed the bargaining power in favour of the buyer more than the supplier. Various reasons support this notion. For example, because buyers find new alternative suppliers and substitutive products easier, the negotiation power of suppliers is lower, which reflects to prices. The competition is more open and thus, the prices are lower which benefits the buyers. Due to the e-business, several functions are transferred to suppliers, which leads to cost and resource effectiveness of buyers and also makes the processes easier for buyer firms. Hence, it could be stated that the change in bargaining power brought about by e-business implementation has benefited the buyer.

\subsection{Competitive position}

The implementation of e-business affects not only the bargaining position and power but also the competitive positions of companies. According to Porter (2001), the internet reduces differences among competitors, widens the geographic market and lowers variable costs. Furthermore, e-business technologies reduce barriers to entry due to the elimination of the need for physical assets.

The utilization of e-business also creates new substitutes. Porter (2001), for example, refers to the proliferation of the internet and the consequent creation of new substitution threats. The conducting of e-business allows the firm to expand its market by reaching out to new customer bases and segments without the limitations of geography and time (Evans and Wurster, 1997). Furthermore, this increases the number of substitutive products and competitors. Especially from the supplier perspective, the internet is increasingly bringing new threats of substitute products or services.

Porter (2001) concludes that although the internet is beneficial in terms of purchasing, marketing and distribution, and allows buyers and sellers to find and transact business with one another more easily, it also makes it more difficult for companies to capture such benefits as profits. He therefore argues that it has negative implications for profitability. Still, e-systems are taking on an even more significant role in business, and companies are being forced to face the challenges created by the new threats. Previous studies (see e.g. Porter, 2001) have referred to the threat of new substitute products and services as a major challenge for companies using e-business.

The electronic market on the internet represents huge potential for suppliers in terms of offering alternative product and raw-materials solutions worldwide. Given that savings in costs and time appear to be the main reason why buying companies use e-business, it may be that the basis of competition has shifted away from quality and service towards price (Porter, 2001). This highlights the significance of competitive strategies and supplier selection from the buyer's perspective. If buyers are seeking lower prices they aim at finding substitutive products and suppliers, which increases the role and power of substitutes. The results of this study support this notion: it was found that the change in competitive position has been to the benefit of substitutes rather than new entrants (see Figure 4). 


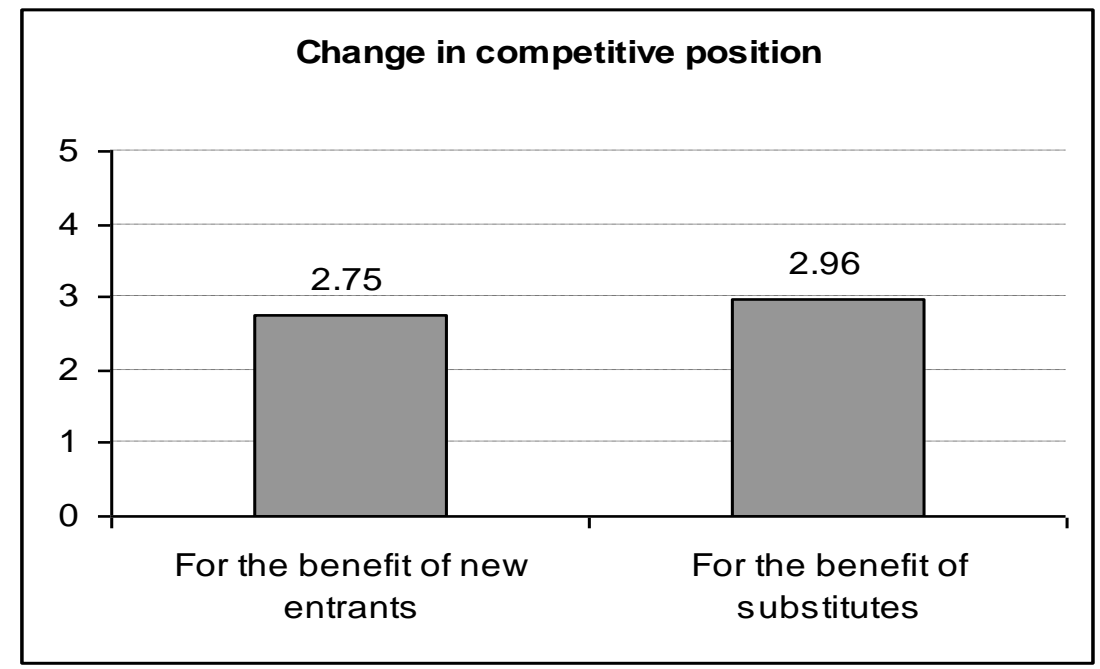

Figure 4. Change in the competitive position.

\section{CONCLUSIONS}

It has been argued in several previous studies that the exploitation of e-business has become one of the primary conditions of doing business in the current environment. It has also been suggested that the implementation of ebusiness technologies will change business patterns in firms, especially in the field of supply management. The results of this study show that e-business has affected supply management in several ways. It has caused many changes, both positive and negative. It has also created new targets and benefits for buyers and suppliers, and modified the structure of industries and supply chains and networks.

The aim in this study was to describe some of the effects of e-business on the firm's supply management, and to discuss the targets and objectives, and the changes in bargaining power and competitive positions it has brought about. These issues were examined empirically by means of survey data collected from one hundred Finnish firms.

Previous research has identified many targets for the implementation of e-business technology, the most important of which according to the results is to save costs. A number of studies also refer to the possibility of further developing processes and the whole business. The results of this study provide similar evidence. The empirical findings point to two main targets of e-business implementation in supply management among the Finnish firms surveyed: savings in cost and time, and development and change in business processes. Hence, it could be concluded that companies aim to save costs and time and also to develop their processes and business by implementing e-business technologies in their supply management.

Previous literature has shown that the internet shapes industry structures through the forces of competition. Bargaining positions between buyers and suppliers have a strategic role in supply management. In that e-business technology has significantly changed supply management and supply activities, it has also affected buyer-supplier relationships. E-business has expanded the market, buyers are able to carry out transactions globally and the number of available suppliers and products has increased remarkably. This is one of the reasons why the market power of buyers has increased. However, e-business also benefits suppliers because, for example, the customer bases have grown. As reported in several previous studies, the results of this study indicate that e-business has changed bargaining power in favour of the buyer more than the supplier.

The implementation of e-business also affects companies' competitive positions. Previous studies have found that it reduces barriers to entry and also creates new substitutes. These forces of competition, on the other hand, affect the firms' competitive positions. The aim of this empirical study was to find out whether e-business has a bigger effect on new substitutes than on entry barriers. The results indicate that the change in competitive position has been to the benefit of substitutes rather than new entrants. It could thus be concluded that even if e-business technology reduces entry barriers by eliminating the need for physical assets, existing suppliers still face many difficulties and challenges. E-business makes it much easier for buyers to access information concerning substitute suppliers and products, and hence the substitutes are more easily found and utilized. It therefore seems that the change in competitive position resulting from e-business implementation is more beneficial to substitutes than to new entrants.

The implementation of e-business technology has also brought several changes to companies' supply management and supply processes. The results of our study show that responsibility for parts of the supply process has shifted to suppliers. The content of the operative work has changed and the quality of business has risen. Moreover, e-business has contributed to the integration of supply management with other company functions. We also found evidence of change in processes related to the supplier relationship. Furthermore, some company tasks have become redundant, but at the same time e-business has also created new tasks.

It could be concluded that e-business has significantly influenced supply management and supply processes in companies. It has also affected their bargaining and competitive positions in chains, networks and industries. It appears from the results of this study that high-flying companies will be the ones that consider e-business an essential element of their business strategy and business model. 


\section{REFERENCES}

Achrol R.S. (1997). Changes in the theory of interorganizational relations in marketing: Toward a network paradigm. Academy of Marketing Science, 25 (1), pp. 56-71.

Allee, V. (2003), The future of knowledge: Increasing prosperity through value networks, Boston, MA, Butterworth-Heinemann.

Amit, R. and Zott, C. (2001). Value creation in e-business. Strategic Management Journal, 22 (6/7), pp. 493-520.

Armstrong J.S. and Overton T.S. (1977). Estimating non response bias in mail surveys. Journal of Marketing Research, 14 (3), pp.396-402.

Bakos J.Y. (1997). Reducing buyer search costs: Implications for electronic marketplaces. Management Science, 43 (12), pp.1676-1692.

Barua A., Konana P., Whinston A.B. and Yin F. (2004). An empirical investigation of net-enabled business value. MIS Quarterly, 28 (4), pp.585-620.

Bates H. and Slack N. (1998). What happens when the supply chain manages you? A knowledge-based response. European Journal of Purchasing \& Supply Management, 4 (1), pp.63-72.

Bovet, D. and Martha, J. (2000), Value nets: Breaking the supply chain to unlock hidden profits, New York, Wiley \& Sons.

Caniato, F., Cagliano, R., Kalchschmidt, M., Golini, R. and Spina, G. (2009). Evolutionary patterns in e-business strategy. International Journal of Operations \& Production Management, 29 (9), pp.921-945.

Chang, H.H., Tsai, Y.-C. and Hsu, C.-H., (2013). Eprocurement and supply chain performance. Supply Chain Management: An International Journal, 18 (1), pp.34-51.

Chong, A., Ooi, K. and Sohal, A. (2009). The relationship between supply chain factors and adoption of eCollaboration tools: An empirical examination. International Journal of Production Economics, 122 (1), pp.150-160.

Cox A. (1997), Business success: A way of thinking about strategy, critical supply chain assets and operational best practice, Earlsgate Press, Winteringham.

Cox A. (1999). Power, value and supply chain management. Supply Chain Management: An International Journal, 4 (4), pp.167-175.

Cox A., Sanderson J. and Watson G. (2001), Power regimes: A new perspective on managing in supply chains and networks, Proceedings of the 10th International Annual IPSERA Conference, Jonkoping, Sweden.

Croom S. (2005). The impact of e-business on supply chain management: An empirical study of key developments. International Journal of Operations \& Production Management, 25 (1), pp.55-73.

Croom S. and Brandon-Jones A. (2007). Impact of eprocurement: Experiences from implementation in the UK public sector. Journal of Purchasing \& Supply Management, 13 (4), pp.294-303.

De Boer L., Harink J. and Heijboer G. (2002). A conceptual model for assessing the impact of electronic procurement. European Journal of Purchasing \& Supply Management, 8 (1), pp.25-33.
Doz Y.L. and Hamel G. (1998), Alliance Advantage: The Art of Creating Value through Partnering, Harvard Business School Press, Boston, Massachusetts.

Essig M. and Arnold U. (2001). Electronic procurement in supply chain management: An information economicsbased analysis of electronic markets. Journal of Supply Chain Management, 37 (4), pp.43-49.

Evans P.B. and Wurster T.S. (1997). Strategy and the new economics of information. Harvard Business Review, 75 (5), pp.70-82.

Giunipero L. and Sawchuck C. (2000), E-purchasing plus: changing the way corporations buy, JGC Enterprises, Goshen, New York.

Goutsos S. and Karacapilidis N. (2004). Enhanced supply chain management for e-business transactions. International Journal of Production Economics, 89 (2), pp.141-152.

Gunasekaran, A., McGaughey, R., Ngai, E. and Rai, B. (2009). E-Procurement adoption in the Southcoast SMEs. International Journal of Production Economics, 122 (1), pp.161-175.

Johnson M.E. and Wang S. (2002). E-business and supply chain management: An overview and framework. Production and Operations Management, 11 (4), pp.413-423.

Johnson P.F. and Klassen R.D. (2005). E-procurement. MIT Sloan Management Review, 46 (2), pp.16-21.

Johnson P.F., Klassen R.D., Leenders M.R. and Awaysheh A. (2007). Utilizing e-business technologies in supply chains: The impact of firm characteristics and teams. Journal of Operational Management, 25 (6), pp.12551274.

Kalakota R. and Robinson M. (2001), e-Business 2.0, Addison-Wesley, Pearson Education.

Kothandaraman, P. and Wilson, D.T. (2001). The future of competition: value-creating networks. Industrial Marketing Management, 30 (4), pp.379-89.

Kritchanchai, D., (2012). A framework for healthcare supply chain improvement in Thailand. Operations and Supply Chain Management 5 (2), pp.103-113.

Kähkönen, A-K. (2012). Value net - A new business model for the food industry?. British Food Journal, 114 (5), pp.681-701.

Kähkönen, A-K. and Virolainen, V.M. (2012). Sources of structural power in the context of value nets. Journal of Purchasing \& Supply Management, 18 (2), pp.68-75.

Lancioni R.A., Smith M.F. and Oliva T.A. (2000). The role of internet in supply chain management. Industrial Marketing Management, 29 (1), pp.45-56.

Lysons K. and Farrington B. (2006), Purchasing and supply chain management, 7th edition, Prentice Hall, Harlow, Essex.

Muffatto, M. and Payaro, A. (2004). Implementation of eprocurement and e-fulfillment processes: A comparison of cases in the motorcycle industry. International Journal of Production Economics, 89 (3), pp.339-351.

Möller K., Rajala A. and Svahn S. (2005). Strategic business nets - Their type and management. Journal of Business Research, 58 (9), pp.1274-1284.

Möller, K. and Rajala, A. (2007). Rise of strategic nets New modes of value creation. Industrial Marketing Management, 36 (7), pp.895-908. 
Panayiotou, N., Gayialis, S. and Tatsiopoulos, I. (2004). An e-procurement system for governmental purchasing. International Journal of Production Economics, 90 (1), pp.79-102.

Parolini, C. (1999), The value net: A tool for competitive strategy, John Wiley \& Sons, Chichester.

Pearcy D.H., Giunipero L.C. and Dandeo L.M. (2004), An analysis of e-procurement strategy: What role does corporate strategy play?, Proceedings of the 13th International Annual IPSERA Conference, Catania, Italy.

Porter M.E. (2001), Strategy and the Internet, Harvard Business Review, 79 (3), 62-78.

Porter. M.E. (2008). The five competitive forces that shape strategy. Harvard Business Review, 86 (1), pp.78-97.

Power, D. (2008). Adoption of supply chain management enabling technologies: Comparing small, medium and larger organizations. Operations and Supply Chain Management, 1(1), pp.31-42.

Ramsay J. (1996). Power measurement. European Journal of Purchasing \& Supply Management, 2 (2-3), pp.129-143.

Sanders N.R. (2007). The benefits of using e-business technology: The supplier perspective. Journal of Business Logistics. 28 (2), pp.177-207.
Smart A. (2008). eBusiness and supply chain integration. Journal of Enterprise Information, 21 (3), pp.227-246.

Stannack P. (1996). Purchasing power and supply chain management power - A response to Ramsay's Purchasing Power (1995). European Journal of Purchasing \& Supply Management, 2 (1), pp.47-56.

Subramaniam C. and Shaw M.J. (2004). The effects of process characteristics on the value of $\mathrm{B} 2 \mathrm{~B}$ eprocurement. Information Technology Management, 5 (1-2), pp.161-180.

Tanner C., Wölfle R., Schubert P. and Quade M. (2008). Current trends and challenges in electronic procurement: An empirical study. Electronic Markets, 18 (1), pp.6-18.

Vakharia A.J. (2002). e-Business and supply chain management. Decision Sciences, 33 (4), pp.495-504.

Wiengarten, F., Fynes, B., Humphreys, P., Chavez, R.C. and McKittrick, A. (2011). Assessing the value creation process of e-business along the supply chain. Supply Chain Management: An International Journal, 16 (4), pp.207-2019.

Zakaria, H., Zailani, S. and Fernando, Y. (2010). Moderating role of logistics information technology on the logistics relationships and logistics service quality. Operations and Supply Chain Management, 3(3), pp.134-147.

Anni-Kaisa Kähkönen, D.Sc., is a Post-Doctoral Researcher in Lappeenranta University of Technology, School of Business. Her current areas of interest include supplier relationships, power relations, supply networks, value creation and supply strategies. She is the corresponding author and can be contacted at: anni-kaisa.kahkonen@lut.fi.

Katrina Lintukangas, D.Sc., is an Associate Professor of Supply Management in Lappeenranta University of Technology, School of Business. Her research interests include supplier relationship management (SRM), global supply management and international business.

Veli Matti Virolainen, D.Sc., is a Professor of Supply Management in Lappeenranta University of Technology, School of Business. His current areas of interest include strategic supply management, supply strategies and risk management. 